\title{
Peran Pendidikan Dan Pengetahuan Ilmu Kimia Dalam Mengembangkan Potensi Pengawetan (Tempoyak Atau Pakasam) Bahan Nabati Dan Hewani Lokal Daerah Kalimantan Tengah
}

\author{
Khusnul Khatimah Yeni Arifianti \\ SMAN 1 Kuala Pembuang, Kalimantan Tengah, Indonesia
}

\begin{abstract}
Abstrak: Peran pendidikan kimia sangat penting dalam pengembangan potensi lokal yang perlu dipelajari peserta didik SMA. Makalah ini bertujuan untuk mengangkat kebudayaan lokal daerah Kalimantan Tengah untuk dapat dipelajari lebih lanjut dan menjadi khazanah dalam pendidikan kimia dalam pengembangan potensi daerah terutama pada teknis pengawetan (Tempoyak atau Pakasam) bahan nabati dan hewani Khas Kalimantan Tengah.Salah satu tantangan yang sudah ada yaitu masyarakat ekonomi ASEAN (MEA), dimana masyarakat di negara ASEAN dapat bersaing bebas menghasilkan produk unggulan dan bebas memasarkannya, dan persaingan keterampilan (skill) dalam dunia kerja. Metode penelitian dilakukan dengan cara kajian pustaka. Data dianalisis secara deskriptif. Hasil kajian pustaka menunjukkan bahwa keilmuan kimia sebagaimana pemaparan pengolah Tempoyak secara kimiawi dengan cara Fermentasi merupakan terobosan dalam mengembangkan potensi yang dimiliki oleh buah durian. Dalam konteks di atas, hubungan antara sains, teknologi, dan masyarakat menjadi penting, sebab seperti kita ketahui, teknologi lahir karena adanya kebutuhan manusia untuk mempermudah segala aktivitas dan kegiatannya, serta untuk meningkatkan kualitas dan daya ekonomis suatu produk sebagaimana pengolah Tempoyak Durian.
\end{abstract}

Kata Kunci: ilmu kimia, pendidikan, potensi lokal, tempoyak

\section{PENDAHULUAN}

Profesi guru merupakan sebuah profesi yang mulia. Guru memiliki peranan penting dalam mengantar generasi muda bangsa yang sesuai dengan Amanat Pembangunan Nasional di dalam UUD 1945, yaitu mencerdaskan kehidupan bangsa yang bermartabat, kreatif, mandiri dan dapat menyesuaikan diri dengan tuntutan globalisasi. Oleh karena itu dalam profesinya guru harus dapat menemukan inovasi-inovasi dalam pembelajaran yang dapat membantu siswa dalam meningkatkan kemampuan (Life Skill) baik segi kognitif, psikomotor dan afektifnya

Inovasi-inovasi tersebut dilakukan agar pembelajaran di Sekolah menjadi lebih bermakna, dan dapat diaplikasikan dalam kehidupan sehari-hari peserta didik, meningkatkan kualitas hidup dan kehidupan dari segi life skill (kemampuan,keterampilan) meliputi aspek kognitif, psikomotor dan sikap.

Peran ilmu sains dalam hal ini ilmu pendidikan kimia dirasa penting untuk mengembangkan potensi-potensi lokal daerah dimana peserta didik tersebut tinggal, sehingga pembelajaran ilmu kimia tersebut tidak hilang begitu saja namun melekat kuat sebagai pemahaman yang dapat diterapkan pada kehidupan nyata. Dengan cara yang berbeda tetapi pada hakikatnya sama, UNESCO menekankan agar belajar tidak hanya bertujuan agar anak didik tahu (to know), tetapi juga anak didik dapat melakukan (to do), dapat hidup bersama (to live together) dan semakin menjadi dirinya (to be) (Delors, 1996 : 97 dalam Salirawati, 2009 dalam Arifianti,2016).

Untuk dapat menciptakan pembelajaran kreatif diperlukan tiga sifat dasar yang harus dimiliki pendidik maupun peserta didik, yaitu peka, kritis, dan kreatif terhadap fenomena yang ada di sekitarnya. Peka artinya orang lain tidak dapat melihat keterkaitannya dengan konsep yang ada dalam otak, tetapi kita mampu menangkapnya sebagai fenomena yang dapat dijelaskan dengan konsep yang kita miliki. Kritis artinya fenomena yang tertangkap oleh mata kita mampu diolah dalam pikiran hingga memunculkan berbagai pertanyaan yang menggelitik kita untuk mencari jawabannya (Salirawati,2009 dalam Arifianti,2016).

Sains berkembang pesat disertai dengan perkembangan teknologi sebagai wujud aplikasi sains. Sains dan teknologi berkembang disesuaikan dengan kompleksitas kebutuhan masyarakat global (Santoso, 2010 dalam Mumpuni https://media.neliti.com). Definisi mengenai sains menurut Sardar (1987, 161) dalam Mumpuni, (https://media.neliti.com) adalah sarana pemecahan masalah mendasar dari setiap peradaban. Tanpa sains, lanjut Sardar $(1987,161)$ suatu peradaban tidak dapat mempertahankan struktur-struktur politik dan sosialnya atau memenuhi kebutuhankebutuhan dasar rakyat dan budayanya. Sebagai perwujudan eksternal suatu epistemologi, sains 
membentuk lingkungan fisik, intelektual dan budaya serta memajukan cara produksi ekonomis yang dipilih oleh suatu peradaban.

Menurut Asmani (2012) dalam Mumpuni (https://media.neliti.com) , salah satu cara untuk menjadi negara maju adalah pemanfaatan sumber daya, kekayaan alam dan budaya sendiri, sehingga mencapai kemandirian dan kepercayaan diri. Oleh karena itu, sekarang pemerintah mencanangkan pendidikan keunggulan lokal untuk diimplementasikan dalam pembelajaran. Pendidikan keunggulan lokal adalah pendidikan yang memanfaatkan keunggulan lokal dalam aspek ekonomi, budaya, bahasa, teknologi informasi, komunikasi, ekologi dan lain-lain yang bermanfaat bagi pengembangan kompetensi siswa.

Keunggulan lokal adalah potensi suatu daerah untuk menjadi produk atau jasa yang bernilai dan dapat menambah penghasilan daerah dan bersifat unik serta memiliki keunggulan kompetitif. Keunggulan lokal harus dikembangkan dari potensi masing-masing daerah. Konsep pengembangan potensi lokal meliputi potensi sumber daya alam, potensi sumber daya manusia, geografis, budaya dan historis. Potensi lokal di Kalimantan Tengah dan di Indonesia pada ,umumnya amat banyak ragamnya, salah satunya adalah teknik pengawetan bahan nabati maupun hewani dengan teknik fermentasi yang dikenal oleh suku Melayu dengan Tempoyak atau Pakasam.

Tempoyak merupakan suatu jenis makanan tradisional yang dibuat dari hasil fermentasi buah durian. Makanan ini sudah menjadi ciri khas bangsa melayu. Walaupun beberapa daerah menggunakan penamaan yang berbeda seperti, pekasam (Aceh) dan asam durian (Sumatera Barat), tapi pada hakikatnya berasal dari makanan yang sama yaitu tempoyak.

Ketika Abdullah bin Abdulkadir berkunjung ke Terengganu (sekitar tahun 1836), dia menyatakan bahwa salah satu kegemaran penduduk setempat adalah tempoyak. Sejarah dalam hikayat ini menyebutkan tempoyak merupakan makanan khas dari malaysia. Tempoyak memiliki peran yang cukup penting di tengah masyarakat keturunan melayu. Pada saat terjadinya musim durian, pembuatan tempoyak merupakan salah satu alternatif mengawetkan buah ini agar dapat digunakan untuk kebutuhan lain pada waktu tertentu. Fungsi pengawetan ini sangat bagus untuk menghindari pembusukan buah yang tidak diinginkan,( Sunandar,2011).

Tempoyak merupakan makanan hasil fermentasi sebagai salah satu upaya pengawetan pangan secara tradisional. Tempoyak mempunyai aroma yang tajam dan rasanya sangat asam dan digolongkan sebagai makanan hasil fermentasi asam laktat. Fermentasi durian serupa dengan fermentasi sauerkraut (asinan kubis), "kimchi" dan asinan buah yaitu fermentasi dengan menambahkan garam dapur pada konsentrasi tertentu yang dapat mendukung aktivitas bakteri asam laktat. (Yuliana, 2009 dalam Sunandar, 2011).

Makalah ini bertujuan untuk mengangkat kebudayaan lokal daerah Kalimantan Tengah untuk dapat dipelajari lebih lanjut dan menjadi khazanah dalam pendidikan kimia dalam pengembangan potensi daerah terutama pada teknis pengawetan (Tempoyak atau Pakasam) bahan nabati dan hewani Khas Kalimantan Tengah.Salah satu tantangan yang sudah ada yaitu masyarakat ekonomi ASEAN (MEA), dimana masyarakat di negara ASEAN dapat bersaing bebas menghasilkan produk unggulan dan bebas memasarkannya, dan persaingan keterampilan (skill) dalam dunia kerja. Tugas institusi pendidikan tidak hanya membekali siswa dengan kemampuan kognitif semata (academic skill), tetapi institusi mampu membekali peserta didik dengan keterampilan (soft skill, hard skill), dan sikap (attitude) (Mujib Ubaidillah, media.neliti.com, 2017).

\section{METODE PENELITIAN}

Definisi Konsepsional

- Peran Pendidikan dan pengetahuan ilmu kimia adalah keikutsertaan pendidikan dan pengetahuan ilmu kimia secara strategis,mempengaruhi dan membentuk sesuatu atau secara umum 'peran' dapat didefinisikan sebagai "expectations about appropriate behavior in a job position (leader, subordinate)". Ada dua jenis perilaku yang diharapkan dalam suatu pekerjaan, yaitu (1) role perception: yaitu persepsi seseorang mengenai cara orang itu diharapkan berperilaku; atau dengan kata lain adalah pemahaman atau kesadaran mengenai pola perilaku atau fungsi yang diharapkan dari orang tersebut, dan (2) role expectation: yaitu cara orang lain menerima perilaku seseorang dalam situasi tertentu, (Bauer, 2003 :55 dalam https://jodenmot.wordpress.com/2012/12/29/teori-peran-pengertian-definisi/). 
- Potensi adalah sebuah kemampuan dasar yang dimiliki manusia atau sesuatu yang sangat mungkin untuk dikembangkan, sehingga pada intinya potensi sendiri berarti suatu kemampuan yang masih bisa dikembangkan dengan tujuan mendapatkan hasil yang lebih maksimal. ( https://pengertiandefinisi.com/pengertian-potensi-dan-jenis-jenisnya/)

- Tempoyak dan pakasam adalah suatu jenis makanan tradisional yang dibuat dari hasil fermentasi buah durian.

\section{Definisi Operasional}

Buah durian umumnya dikonsumsi segar yaitu langsung dikonsumsi,dibuat sari buah atau ditambahkan ke dalam es krim. Untuk memperpanjang masa simpan dan penganeka ragaman produk. Durian dapat pula diolah melalui serangkaian pengolahan - pengolahan. Pengolahan daging durian dapat dikategorikan sebagai pengolahan yang melibatkan mikroba atau diproses secara mikrobiologi (fermentasi) dan pengolahan secara fisika kimia (non-fermentasi). Pengolahan secara mikrobiologi merupakan proses pengolahan yang melibatkan bakteri asam laktat atau fermentasi. Produk yang dihasilkan dikenal dengan sebutan tempoyak.

Dalam ilmu kimia proses ini dipelajari dalam pokok bahasan reaksi kimia organik dimana Fermentasi adalah proses produksi energi dalam sel dalam keadaan anaerobik (tanpa oksigen). Secara umum, fermentasi adalah salah satu bentuk respirasi anaerobik, akan tetapi, terdapat definisi yang lebih jelas yang mendefinisikan fermentasi sebagai respirasi dalam lingkungan anaerobik dengan tanpa akseptor elektron eksternal. (https://id.wikipedia.org/wiki/Fermentasi)

\section{Waktu dan Tempat Penelitian}

Penelitian ini di laksanakan pada tanggal 15 Oktober 2017. Penelitian ini di laksanakan di Kalimantan Tengah dengan memadukan beberapa informasi mengenai potensi lokal buah durian dalam pengawetan dengan metode fermentasi (Tempoyak) yang diberikan oleh beberapa penelitian terdahulu secara kajian pustaka.

Data penelitian ini diambil dari makalah-makalah penelitian mengenai mekanisme kimia tempoyak durian yang ada dan populer di Kalimantan Tengah, Obyek yang diamati adalah Peran ilmu kimia dalam mengembangkan pembuatan Tempoyak Durian.

Dokumen yang dibutuhkan untuk melakukan penelitian ini adalah ;

- Buku-buku yang sesuai atau berkaitan

- Laptop

- Internet (Website makalah tentang pengolahan tempoyak secara kimiawi)

- Dan tambahan literatur lainya

Metodologi Pengambilan Data (disesuaikan)

Karena data tidak diperoleh dari penelitian secara langsung atau melakukan uji laboratorium. Data yang disajikan berupa penjabaran pada tinjauan pustaka tentang apa yang diteliti yaitu Peran Pendidikan dan Pengetahuan Ilmu Kimia dalam Mengembangkan Potensi Pengawetan (tempoyak atau pakasam) Bahan Nabati dan Hewani Lokal Daerah Kalimantan Tengah dari buku-buku yang sesuai atau berkaitan dan literatur tambahan seperti internet.

\section{HASIL PENELITIAN DAN PEMBAHASAN}

Belajar akan sangat menyenangkan ketika materi yang dijelaskan ada kaitannya dengan kehidupan kita sehari-hari. Ausubel (1991) dalam Arifianti (2016) menyatakan belajar akan bermakna jika anak didik dapat mengaitkan konsep yang dipelajari dengan konsep yang sudah ada dalam struktur kognitifnya, dan Bruner (1991)dalam Arifianti, (2016) menyatakan belajar akan berhasil lebih baik jika selalu dihubungkan dengan kehidupan orang yang sedang belajar (anak didik).

Meskipun classical dan operant conditioning dalam hal-hal tertentu masih merupakan tipe penting dari belajar, namun orang belajar tentang sebagian besar apa yang ia ketahui melalui observasi (pengamatan). Belajar melalui pengamatan berbeda dari classical dan operant conditioning karena tidak membutuhkan pengalaman personal langsung dengan stimuli, penguatan kembali, maupun hukuman. Belajar melalui pengamatan secara sederhana melibatkan 
pengamatan perilaku orang lain, yang disebut model, dan kemudian meniru perilaku model tersebut. (Bryn Holmes, 2001 dalam Arifianti 2016).

Dengan demikian adalah penting melakukan kajian tentang pengembangan potensi lokal daerah Kalimantan Tengah tempat proses pembelajaran berlangsung sebagaimana diangkat dalam penelitian ini. Kalimantan Tengah merupakan daerah yang masyarakatnya amat menggemari buah durian atau "The King of Fruits" ini. Klasifikasi Durian : Kingdom : Plantae Divisi : Spermatophyta Kelas : Magnoliopsida Ordo : Malvales Famili : Malvaceae Genus : Durio Spesies : D. zibethinus Sumber : (Dewayani, 1997) Durian terutama dipelihara orang untuk buahnya, yang umumnya dimakan (arilus atau salut bijinya) dalam keadaan segar. Salut biji ini umumnya manis dan sangat bergizi karena mengandung banyak karbohidrat, lemak, protein, dan mineral. Setiap $100 \mathrm{~g}$ salut biji mengandung $67 \mathrm{~g}$ air, 28,3 g karbohidrat, 2,5 g lemak, 2,5 g protein, 1,4 g serat; serta memiliki nilai energi sebesar $520 \mathrm{~kJ}$. Untuk memperpanjang masa simpan dan penganekaragaman produk. Durian dapat pula diolah melalui serangkaian pengolahan pengolahan. Pengolahan daging durian dapat dikategorikan sebagai pengolahan yang melibatkan mikroba atau diproses secara mikrobiologi (fermentasi) dan pengolahan secara fisika kimia (nonfermentasi).

Pengolahan secara mikrobiologi merupakan proses pengolahan yang melibatkan bakteri asam laktat atau fermentasi. Produk yang dihasilkan dikenal dengan sebutan tempoyak. Sedangkan produk olahan durian yang tidak melibatkan mikrobiologi umumnya adalah lempok, selai, fruit leather, dodol, keripik durian dan lain - lain. Durian sebagai bahan utama tempoyak ternyata memiliki gizi yang cukup baik.

Buah yang biasa dijuluki â?] King of Fruitâ?] ini mengandung mengandung vitamin $\mathrm{B}, \mathrm{C}$, E dan zat besi dan memiliki nilai energy sebesar $520 \mathrm{~kJ}$. Selain itu juga, durian memiliki manfaat berupa sebagai pembersih darah, mengandung protein lembut sehingga sering dikonsumsi oleh orang yang ingin membentuk otot, karena mengandung asam amino triptofan, durian mampu mengurangi rasa gelisah, depresi dan mengobati insomnia. (https://dokumen.tips/documents/makalah-mikroindustritempoyak.html).

Pengolahan durian yang dilakukan secara fermentasi tersebut menghasilkan produk yang dikenal dengan nama tempoyak, pikel durian, pekasam atau durian asam (Ekowati,C.N, 1988) (https://dokumen.tips/documents/makalah-mikroindustritempoyak.html. Durian fermentasi atau tempoyak digunakan sebagai bumbu masakan di beberapa daerah beretnis Melayu seperti Lampung, Jambi, Sumatera Selatan, Sumatera Barat (juga dikenal sebagai durian asam), Aceh (disebut Pekasam) dan Kalimantan.

Pada makalah ini penulis menggunakan nama tempoyak, karena nama ini yang paling banyak digunakan di masyarakat beretnis Melayu. Untuk menghasilkan tempoyak, buah durian difermentasi dengan penambahan garam yang melibatkan mikroorganisme bakteri asam laktat (Irwandi dan Che-Man, 1996; Morton, 1987; Battcock dan Ali, 1998; Gandjar, 2000; Yuliana, 2004 dalam Yuliana, 2007), sehingga fermentasi durian menjadi tempoyak termasuk ke dalam fermentasi bakteri asam laktat. Penambahan garam menyebabkan penarikan air dan bahan - bahan bergizi dari jaringan bahan yang difermentasi, yang kemudian akan digunakan sebagai substrat bagi pertumbuhan bakteri yang terlibat dalam fermentasi. Fermentasi daging durian menjadi tempoyak dapat dilakukan secara spontan dan atau dengan penambahan kultur atau ragi. Umumnya pembuatan tempoyak di masyarakat dilakukan secara tradisional dan sifatnya spontan tanpa penambahan inokulum atau kultur murni.

Hal yang harus diperhatikan pada pengolahan durian secara fermentasi adalah terciptanya kondisi anaerobik sampai sedikit aerobik, karena fermentasi melibatkan bakteri asam laktat yang bersifat aerofilik (kondisi sedikit aerobik). .Dengan demikian bahan fermentasi harus seimbang dengan wadah fermentasi sedemikian rupa sehingga hanya tersisa sedikit ruang antara bahan dan tutup wadah. Jika terlalu penuh, kemungkinan akan terjadi desakan tutup oleh gas yang dihasilkan selama fermentasi, sedangkan jika terlalu banyak ruang kosong kondisi anaerobic kurang terbentuk akibatnya terjadi peluang kontaminasi. Penambahan garam pada pembuatan tempoyak di masyarakat sangat bervariasi $(2,5 \%$ sampai dengan $30 \% \mathrm{~b} / \mathrm{b})$. Secara garis besar kandungan garam yang ditambahkan dapat menghasilkan dua jenis tempoyak yang berbeda yaitu tempoyak asam jika kandungan garam kurang dari 5\% dan tempoyak asin jika diberi penambahan garam lebih dari $5 \%$. Kandungan garam yang rendah akan lebih mendukung pertumbuhan bakteri asam laktat sehingga produk akhir mempunyai tingkat keasaman tinggi dalam waktu yang relative lebih cepat dibandingkan dengan tempoyak yang diberi garam tinggi. 
Namun demikian, tempoyak yang dihasilkan dengan garam tinggi lebih awet dibandingkan dengan yang bergaram rendah. Penambahan garam pada bahan akan menyebabkan pelepasan cairan dari bahan dasar. Cairan tersebut mengandung gula, protein terlarut, mineral dan zat-zat lain yang dapat digunakan sebagai substrat oleh bakteri asam laktat (BAL). Larutan garam juga berfungsi sebagai media selektif pertumbuhan mikroorganisme.

Ujicoba produksi termpoyak secara terkontrol menggunakan starter bakteri asam laktat (Pediococcus acidiliactici) menunjukkan penambahan inokulum dapat memperbaiki karakter tempoyak secara mikrobiologi, yaitu total BAL lebih banyak dan tumbuhnya kontaminan (nonbakteri asam laktat) dapat dicegah. Penambahan inokulum juga terbukti membuat waktu fermentasi tempoyak menjadi lebih singkat yaitu 2 - 4 hari (Veramonika, 2005) dari umumnya 710 hari. Pada tempoyak yang diberi inokulum, sejak awal fermentasi bakteri yang terlibat adalah Pediococcus acidilactici. Keberadaan bakteri ini yang dominan pada awal fermentasi akan menekan pertumbuhan mikroba lainnya. Tempoyak yang tidak diberi inokulum memiliki mikroba selain BAL seperti khamir, jamur, dan bakteri lainnya sehingga tempoyak yang diberi inokulum $104 \mathrm{cfu} / \mathrm{g}$ dan $108 \mathrm{cfu} / \mathrm{g}$ lebih baik dibandingkan dengan tanpa inokulum. Penggunaan BAL sebagai starter atau inokulum pada produk-produk fermentasi yang lain juga menunjukkan hasil yang baik (Nurbaiti, 2005 dalam Yuliana, 2007).

Reaksi kimia yang terjadi dalam proses pembuatan tempoyak adalah reaksi fermentasi asam laktat hetero fermentatif. Artinya, selama proses terbentuknya produk tempoyak tidak hanya menghasilkan asam laktat saja (homfermentatif) tapi juga menghasilkan produk asam organik lainnya. Diantara produk asam organik tersebut adalah; asam asetat, asam propionat dan $\mathrm{CO}_{2}$.

Dalam proses reaksi fermentasi, senyawa glukosa yang terdapat di dalam daging durian akan diubah oleh Bakteri Asam Laktat (BAL) yaitu; Lactobacillus casei dan Lactobacillus fersantum menjadi gkulosa-6-P. Kemudian diubah menjadi Gluconat-5P dan berubah lagi menjadi Xilose 5-P-CO2. Xilose-5-P- $\mathrm{CO}_{2}$ nantinya akan terurai menjadi dua senyawa yaitu; Trose-3P dan Acetyl P.

Senyawa Trose-3P akan diubah menjadi senyawa asam piruvat. Kemudian barulah diubah lagi menjadi senyawa asam laktat. Diperkirakan kemampuan menghasilkan asam laktat ini berlangsung sekitar 5 hingga 7 hari. Beberapa hari berikutnya, barulah senyawa ini akan terurai menjadi asam propionat, asam asetat dan $\mathrm{CO}_{2}$.

\section{Berikut alurnya secara lengkap:}

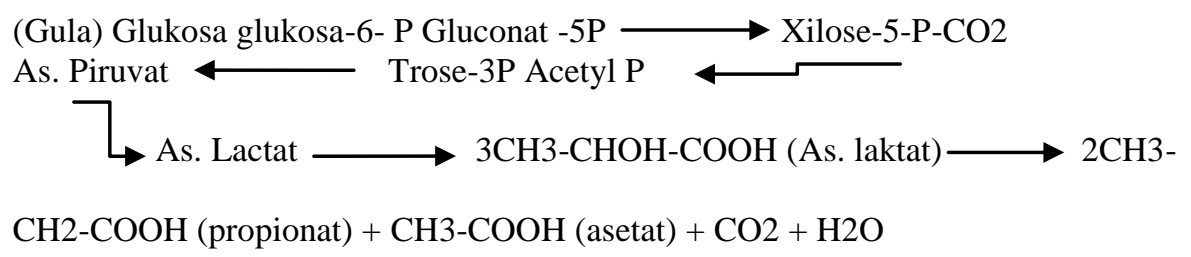

\section{Gambar 1. Bagan alur reaksi kimia terbentuknya tempoyak}

Tempoyak yang bagus berlangsung pada saat kadar asam laktat masih berada dalam kosentrasi yang tinggi. Peningkatan kosentrasi asam laktat berlangsung setelah penyimpanan selama 5 hingga 7 hari. Setelah lewat 7 hari, asam organik lain seperti asam propionat dan asam asetat akan mengalami peningkatan kosentrasi nantinya.

Tempoyak yang bagus adalah yang sesuai dengan standar Departemen Kesehatan. Standar Departemen Kesehatan untuk tempoyak yang bagus adalah:

1. Organoleptik

Uji organoleptik adalah pengujian makanan tempoyak dengan menggunakan organ panca indra. Standar aroma yang bagus untuk tempoyak adalah berkisar pada nilai 3, 22. Standar warnanya sekitar 3,31 dan standar rasanya dengan nilainya 3, 23. (Hanum, 2008)

2. $\mathrm{pH}$

Nilai keasaman yang bagus untuk tempoyak adalah berkisar pada $\mathrm{pH} 3-4$. Tingkat keasaman akan berbeda seiring dengan lamanya penyimpanan. Menurut Amin (2004), hubungan antara keasaman dengan waktu fermentasi dapat dilihat pada grafik dibawah ini: 
Jika kita lihat grafik tersebut maka lama penyimpanan sangat mempengaruhi kadar keasaman. Penyimpanan dibawah 4 hari akan menyebabkan nilai PH masih berkisar antara 4,5 sampai 7 . 3. Kadar air

Kadar air adalah kandungan air yang standar yang terdapat didalam makanan tempoyak. Standar departemen kesehatan untuk kadar air adalah sebesar 53,8 \%.

4. Lama penyimpanan

Penyimpanan yang terlalu lama dapat mempengaruhi kadar keasaman yang terdapat dalam tempoyak. Penyimpanan yang kurang dari 5 hari biasanya kadar keasamannya masih rendah. Sedangkan jika disimpan lebih diatas 7 hari akan menyebabkan keasaman tempoyak akan mengalami perubahan juga. Jika disimpan diatas 5 hingga 7 hari, maka kadar keasaman dari asam laktat akan mengalami penurunan sehingga standar kesehatan tidak terpenuhi.

Perkembangan sains dan teknologi pada keilmuan kimia sebagaimana pemaparan pengolah Tempoyak secara kimiawi dengan cara Fermentasi merupakan terobosan dalam mengembangkan potensi yang dimiliki oleh buah durian. Dalam konteks di atas, hubungan antara sains, teknologi, dan masyarakat menjadi penting, sebab seperti kita ketahui, teknologi lahir karena adanya kebutuhan manusia untuk mempermudah segala aktivitas dan kegiatannya, serta untuk meningkatkan kualitas dan daya ekonomis suatu produk sebagaimana pengolah Tempoyak Durian. Adapun metode pengintegrasian muatan lokal Tempoyak Durian dan proses pengolahannya secara Fermentasi kimia-biologis di Pembelajaran SMA adalah pada pokok Bahasan Reaksi Kimia Organik, Asam-Basa dan Kimia Bahan Makanan dengan kompetensi dasar sebagai berikut ; Mendeskripsikan teori asam-basa menurut Bronsted-Lowry dan Lewis, Mendeskripsikan tata nama senyawa anorganik dan organik sederhana serta persamaan reaksinya, Mengolah dan menganalisis data terkait massa molekul relatif, persamaan reaksi, hukum-hukum dasar kimia, dan konsep mol untuk menyelesaikan perhitungan kimia,

Menganalisis sifat larutan berdasarkan konsep asam basa dan/atau $\mathrm{pH}$ larutan, Menentukan konsentrasi/kadar asam atau basa berdasarkan data hasil titrasi asam basa, Menganalisis kelimpahan, kecenderungan sifat fisik dan sifat kimia, manfaat, dampak, proses pembuatan unsur-unsur golongan utama (gas mulia, halogen, alkali dan alkali tanah, periode 3) serta unsur golongan transisi (periode 4) dan senyawanyadalam kehidupan sehari-hari, Menganalisis struktur, tata nama, sifat dan kegunaan senyawa karbon (halo alkana, alkanol, alkoksi alkana, alkanal, alkanon, asam alkanoat, dan alkil alkanoat), Menganalisis struktur, tata nama, sifat, dan kegunaan benzena dan turunannya , Menganalisis struktur, tata nama, sifat dan penggolongan makromolekul (polimer, karbohidrat, dan protein).

Dalam Ranah Kognitif tertuang pada kompetensi inti ke 3 yaitu Memahami, menerapkan, menganalisis pengetahuan factual, konseptual, prosedural, berdasarkan rasa ingin tahunya tentang ilmu pengetahuan, teknologi, seni, budaya, dan humaniora dengan wawasan kemanusiaan, kebangsaan, kenegaraan, dan peradaban terkait penyebab penomena dan kejadian, serta menerapkan pengetahuan procedural pada bidang kajian yang spesipik sesuai dengan bakat dan minatnya untuk memecahkan masalah dan pada ranah psikomotor atau keterampilan kompetensi yang harus dicapai adalah peserta didik dapat Mengolah, menalar, dan menyaji dalam ranah konkret dan ranah abstrak terkait dengan pengembangan dari yang dipelajarinya di sekolah secara mandiri, dan mampu menggunakan metoda sesuai kaidah keilmuan.

Dengan demikian untuk meningkatkan kualitas dari potensi lokal daerah Kalimantan Tengah seperti buah-buahan durian agar dapat bertahan lama dengan memiliki manfaat lebih banyak selain dikonsumsi secara segar, salah satunya adalah dengan pembuatan Tempoyak. Peran pengetahuan Kimia terutama kimia asam, reaksi kimia, kimia organik ( adanya Peningkatan kosentrasi asam laktat setelah penyimpanan Tempoyak selama 5 hingga 7 hari. Setelah lewat 7 hari, asam organik lain seperti asam propionat dan asam asetat juga akan mengalami peningkatan kosentrasi nantinya) sangat penting. Sehingga dengan adanya relevansi pembelajaran ilmu kimia terhadap perkembangan teknik pengawetan buah durian sebagaimana dipaparkan diatas, dapat dikatakan bahwa potensi local di daerah Kalimantan Tengah dapat berkembang melalui pendidikan dan pengetahuan Kimia. Bahwa kualitas suatu bahan dapat ditingkatkan dengan menerapkan pengetahuan kimia yang dapat diintegrasikan pada kurikulum pembelajaran di Sekolah, terutama Sekolah Menengah Atas dengan Kompetensi yang telah dijabarkan diatas.

Dengan Informasi yang dipaparkan melalui kajian Pustaka pada makalah ini dapat menambah kebermaknaan mempelajari ilmu kimia dengan pemilihan metode pembelajaran yang tepat dan berkesinambungan, agar ketika peserta didik berada di tengah masyarakat maka pengetahuan ini dapat diterapkan untuk meningkatkan kualitas hidup dan mengangkat kebudayaan 
lokal daerah Kalimantan Tengah, dipelajari lebih lanjut dan menambah khazanah dalam pendidikan kimia untuk pengembangan potensi daerah terutama pada teknis pengawetan (Tempoyak atau Pakasam) bahan nabati dan hewani Khas Kalimantan Tengah.Dan menjawab tantangan masyarakat ekonomi ASEAN (MEA), dimana masyarakat di negara ASEAN dapat bersaing bebas menghasilkan produk unggulan dan bebas memasarkannya, dan persaingan keterampilan (skill) dalam dunia kerja. Tugas institusi pendidikan adalah membekali siswa dengan kemampuan kognitif (academic skill), serta membekali peserta didik dengan keterampilan (soft skill, hard skill), dan sikap (attitude) (Mujib Ubaidillah, media.neliti.com, 2017). Dengan pengetahuan yang mumpuni terhadap pemanfaatan sains kimia untuk mengembangkan potensi lokal daerah dan meningkatkan nilai produksi produk local.

\section{KESIMPULAN}

Perkembangan sains dan teknologi pada keilmuan kimia sebagaimana pemaparan pengolah Tempoyak secara kimiawi dengan cara Fermentasi merupakan terobosan dalam mengembangkan potensi yang dimiliki oleh buah durian. Dalam konteks di atas, hubungan antara sains, teknologi, dan masyarakat menjadi penting, sebab seperti kita ketahui, teknologi lahir karena adanya kebutuhan manusia untuk mempermudah segala aktivitas dan kegiatannya, serta untuk meningkatkan kualitas dan daya ekonomis suatu produk sebagaimana pengolah Tempoyak Durian.

\section{DAFTAR RUJUKAN}

Amin, Mat Amiza. 2004. Effect of Salt on Tempoyak Fermentation and Sensory Evaluation. (http://www.researchgate.net)

Arifianti, Khusnul Khatimah Yeni. 2016. Silabus Pembelajaran Kimia untuk SMA. Dokumen Perangkat Pembelajaran Kurikulum 2013. SMAN 1 Kuala Pembuang.

Arifianti, Khusnul Khatimah Yeni. 2016. PTK Meningkatkan Kemampuan Siswa Dalam Pembelajaran Materi Internet di kelas XI semester 1 Tahun Pelajaran 2015-2016 SMAN 1 Kuala Pembuang, menggunakan model pembelajaran Picture and Picture. MGMP TEKNOLOGI INFORMASI DAN KOMUNIKASI (TIK)TAHUN PELAJARAN 2015 2016. Kuala Pembuang. SMAN 1 Kuala Pembuang.

Anonim. 1970. Isi Kandungan Gizi Tempoyak Durian. (http://www.organisasi.org/1970/01/isikandungan-gizi-tempoyak-durian-komposisi-nutrisi-bahan-makanan.html)

Hanum,Chairani.2008. Teknik Budidaya Tanaman Jilid 2 SMK.Jakarta.Direktorat Pembinaan SMK. (http://www.slideshare.net)

Herawati, Heni. 2012. Khasiat dan Manfaat Buah Durian Untuk Kesehatan. (http://www.kreasimasakan.blogspot.co.id)

Jodenmot.2005. Teori Peran, Pengertian dan Definisi Peran. (https://jodenmot.wordpress.com)

Mumpuni.2012. Potensi Lokal. (https://media.neliti.com)

Ubaidillah, Mujib. 2017. Pembelajaran Berbasis Proyek Untuk Mengembangkan Ensiklopedia Berbasis Bioedupreneurship. Volume 05 nomor 01 Maret 2017.Cirebon. (https://media.neliti.com)

Sagala, Jefri. 2014. Fermentasi Buah Durian sebagai penghasil asam propionat dan asam asetat. Universitas Medan (http://www.jefriluanti.blogspot.com)

Purba, Michael.2006. KIMIA UNTUK SMA KELAS XII . KTSP 2006. Jakarta. Erlangga

Reli, Rapeka. Warsiki, Endang. Rahayuningsih, Mulyorini. 2016. Modifikasi Pengolahan Durian Fermentasi (Tempoyak) Dan Perbaikan Kemasan Untuk Mempertahankan Mutu dan Memperpanjang Umur Simpan. (http://www.ipb.ac.id). Bogor . Copyright Central Library of Bogor Agricultural University.

Sunandar. (2011). Pembuatan tempoyak (asam durian). (http://www.aisharaudhatul. wordpress.com)

Wikipedia. 2010 .Tempoyak. ( http://www.wikipedia.com )

Purba, Michael.2006. KIMIA UNTUK SMA KELAS XII . KTSP 2006. Jakarta. Erlangga

Makalah Mikro Industri,Tempoyak. (https://www.scribd.com)

Yuliana, Neti.2007.Pengolahan Durian (Durio Zibethinus) Fermentasi (Tempoyak). Jurnal Teknologi dan Industri Hasil Pertanian Volume 12, No.2, (http://www.academia.edu) 